\section{Physical activity and associated factors in homosexual men}

\section{Atividade física e fatores associados em homens homossexuais}

\author{
Fabiano Augusto Teixeira ${ }^{1}$ \\ Fabiana Flores Sperandio' \\ Fernando Luiz Cardoso
}

\begin{abstract}
This study aimed to estimate the proportion of physically active men proportion of physically active men and investigate what factors may be associated with physical activity in men with bisexual and homosexual orientation. Six hundred and forty six men participated in the study, of whom $571(88.4 \%)$ were homosexual and $75(11.6 \%)$ were bisexual. A self-administered questionnaire was used to collect information on current age, age at first sex, body mass index (BMI), education level, marital status, perception of body image, gender orientation, and sexual orientation. Analyses used descriptive statistics and logistic regression, with the significance level set at 5\%.Among homosexuals, physical activity was associated with masculine orientation, level of education, and dissatisfaction with body image due to being overweight. Physically active homosexuals were 9.93 times more likely to perceive themselves as masculine, 5.29 times more likely to have lower literacy levels, and 4.71 times more likely to have a partner. In conclusion, we found that homosexual men were physically active, dissatisfied with their body image, had a masculine orientation, and were in the normal weight range. This study may increase participants' awareness of the need for a healthy, physically active lifestyle.
\end{abstract}

\section{KEYWORDS}

Physical Activity; Sexual Orientation; Homosexuality.

\section{RESUMO}

Este estudo objetivou estimar a proporção de homens fisicamente ativos e investigar quais os fatores que podem estar associados à prática de atividade física, em bomens com orientação sexual bissexual e bomossexual. Participaram 646 bomens, sendo 571 (88,4\%) bomossexuais e 75 (11,6\%) bissexuais. Para a coleta das informações utilizou-se um questionário autoaplicado contendo informações acerca da idade, IMC, idade da primeira relação sexual, grau de escolaridade, situação conjugal, percepção da imagem corporal, orientação de gênero e orientação sexual. Utilizou-se a estatística descritiva e a regressão logística, considerando o nível de significância de $5 \%$ em todas as análises. A partir dos dados obtidos, encontrou-se associação entre os homossexuais ativos fisicamente e a orientação de gênero masculino (IC 95\% 4,89 - 19,34; 4,13 - 23,86), o grau de escolaridade (IC 95\% 2,28 - 9,03; 2,52 - 11,08) e a insatisfação com a imagem corporal por excesso (IC 95\% 0,12 - 0,55; 0,11 - 0,26). Assim, teve-se que ser fisicamente ativo tem 9,93 vezes mais chances de ocorrer em bomossexuais que se autopercebem com orientação de gênero masculino, 5,29 mais chances em bomossexuais com menos escolaridade e, por fim, 4,71 mais chances em homossexuais com companheiro. Conclui-se que os homens homossexuais são fisicamente ativos, estão insatisfeitos com a imagem corporal, consideram-se com orientação de gênero masculino e foram classificados como eutróficos. A partir dos dados obtidos e considerando a necessidade de um estilo de vida saudável, espera-se que esses individuos adquiram um estilo de vida saudável e adote para si os benefícios dessa prática relacionados a atividade física.

\section{PALAVRAS-CHAVE}

Atividade física; Orientação sexual; Homossexualidade.
Rev Bras Ativ Fís Saúde p. 73-81 DOI

http://dx.doi.org/10.12820/rbafs.v.20n1p73

1 Santa Catarina State University, College of Health and Sport Science, Florianópolis, SC. Brazil. 


\section{INTRODUCTION}

In recent decades, there has been a steady increase in the amount of scientific information produced and published in different fields about physical activity. The various benefits of physical activity have been demonstrated in both the national ${ }^{1,2}$ and the international literature ${ }^{3}$. More specifically, researchers have confirmed the importance of physical activity to the maintenance of health and well-being.

Nevertheless, according to the latest census conducted by the Brazilian Institute of Geography and Statistics ${ }^{4}, 46 \%$ of Brazilians do not engage in enough physical activity to be considered physically active. In order to be considered sufficiently active, a person should strive to achieve at least 150 minutes of physical activity per week. ${ }^{5}$ According to a study, physical activity tends to decline with advancing age ${ }^{6}$. Although physical activity can prevent diseases and promote health, it is understood that the prevalence of low-level physical activity remains high. ${ }^{7}$

Certain factors may be associated with physical inactivity, such as a lack of appropriate places to exercise and fast-paced modern lifestyles. ${ }^{8}$ Individuals who tend to be less physically active on a regular basis include older people, ${ }^{9}$ those with non-communicable chronic diseases, ${ }^{10,11}$ and people with special needs. ${ }^{8}$

In the literature, it has been well established that physical activity may be influenced by multiple factors, including age, socio-demographic and socio-economic factors, education, lifestyle, smoking, eating habits, stress, and gender. ${ }^{12,13}$ This study aims to fill a gap in the literature by investigating factors associated with physical activity in men, taking into account their sexual orientation. We would like to examine whether a man's sexual orientation influences his health-related behaviors and attitudes.

\section{METHODS}

This study was approved by the Ethics Committee for Research with Human Beings of the University of Santa Catarina, number 722.104.

The study enrolled 646 male beach-goers older than 18 years of age in Florianopolis, Santa Catarina, Brazil. In addition to local residents, this study also included participants who were residents of other states in Brazil (from all 5 regions of Brazil). The city where data collection took place (Florianópolis) is located in a tourist area, surrounded by 42 beaches. Florianópolis is a preferred city for lesbians, gay men, bisexuals and transvestites and is considered the second national capital of this public.

Potential participants were approached on the beach in Florianópolis (SC) during the summer and received information on the study objectives. Then they were invited to participate in the study. Those subjects who agreed to participate answered the self-administered questionnaires where they were (at the beach). In order to ensure anonymity, all completed questionnaires were deposited it into a sealed "ballot box". The box was only opened after all questionnaires had been collected.

Individuals meeting the following criteria were included in this study: (A) male gender; (B) homosexual orientation; (C) aged at least 18 years at the time of data collection; and (D) anonymous completion of the whole questionnaire 
Data were collected through a self-administered questionnaire containing information on age, BMI, age at first sex, education level, marital status, perception of body image, gender orientation and sexual orientation. Gender orientation (masculine, feminine or androgynous) was assessed with a escale ${ }^{14}$, in which a score of 0 means exclusively male, a score of 6 indicates that a person perceives him/herself as exclusively female, and a score of 3 means androgynous.

Weight and height values were self-reported by participants. The validity of these measures has been demonstrated for the Brazilian adult population. ${ }^{15}$ We used the cutoff points for classification of body mass index (BMI) established by the literature. ${ }^{16}$ Due to the low frequency of participants reporting underweight (only two), we opted to group participants into classes. Thus, subjects were divided into classes based on their BMI: "normal weight" (which included underweight and normal-weight participants) and "overweight".

A body image scale which includes drawings of nine silhouettes ranging from extremelythin to extremely heavy in appearance ${ }^{16}$ was used to assess body satisfaction. The participant is instructed to: 1) "Please select the silhouette that most accurately depicts your body sizeas you perceive it to be", and 2) "Please select the silhouette that most accurately depicts the body size that you would most prefer".

From these ratings, body dissatisfaction was calculated as current minus ideal. Scores ranged from -8 to +8 , with: -8 to -1 indicating that the subject is dissatisfied with his/her body image due to being underweight; 0 indicating that the person is satisfied; and 1 to 8 indicating that the participants is dissatisfied due to being overweight.

Physical activity level was assessed with the question: "Do you exercise regularly?" Following the recommendations of previous studies, subjects were defined as physically active if they participated in moderate or vigorous activity for at least 150 minutes per week; and subjects were defined as insufficiently physically active if they participated in moderate or vigorous activity for less than 150 minutes per week. ${ }^{13}$

Next, we performed logistic regression analysis and estimated the odds ratio (odds ratio) and $95 \%$ confidence intervals to determine the association between physical activity and the independent variables. We used descriptive analyses (absolute and relative frequency values) to characterize the sample. The chi-square test was used to determine the association between physical activity and the independent variables of gender orientation, level of education, marital status, BMI and body image.

The data were processed and analyzed using Statistical Package for Social Sciences (SPSS), version 20.0. The significance level was set at $\mathrm{p}<0.05$.

\section{RESULTS}

Mean age, mean age at first sex and mean BMI of participants are illustrated in Table 1 .

We found that most study participants $(61.30 \%)$ had an education level above high school graduation. $94.12 \%$ were single. $69.70 \%$ were dissatisfied with their body image: $55 \%$ because they considered themselves overweight and $14.70 \%$ because they considered themselves underweight. $96.96 \%$ perceived themselves 
as masculine. $35.60 \%$ of participants were defined by their BMI as overweight and $11.30 \%$ were insufficiently physically active, as shown inTable 2 .

TABLE 1 - Characterization of study participants with regard to age, height, weight, BMI, age at first sex,perception of body image, gender orientation, level of education and level of physical activity. Florianópolis, Santa Catarina, Brazil, 2014.

\begin{tabular}{lc}
\hline Variable & $x(s d)$ \\
\hline Age lyears) & $26.49(6.20)$ \\
\hline BMI (Kg/m²) & $23.96(2.79)$ \\
\hline Age at first sex & $15.89(1.65)$ \\
\hline Level of education & $n(\%)$ \\
\hline High school diploma & $250(38.70)$ \\
\hline Higher education diploma & $396(61.30)$ \\
\hline Marital status & $\mathrm{n}(\%)$ \\
\hline No partner & $608(94.12)$ \\
\hline Partner & $38(5.88)$ \\
\hline Perception of body image & $\mathrm{n}(\%)$ \\
\hline Satisfied & $196(30.30)$ \\
\hline Dissatisfied due to being overweight & $355(55.00)$ \\
\hline Dissatisfied due to being underweight & $95(14.70)$ \\
\hline Gender orientation & $\mathrm{n}(\%)$ \\
\hline Male & $607(93.96)$ \\
\hline Female & $39(6.04)$ \\
\hline BMI & $\mathrm{n}(\%)$ \\
\hline Normal weight & $416(64.40)$ \\
\hline Overweight & $230(35.60)$ \\
\hline Physical Activity & $\mathrm{n}(\%)$ \\
\hline Insufficiently active & $73(11.30)$ \\
\hline Active & $573(88.70)$ \\
\hline Sexual orientation & $\mathrm{n}(\%)$ \\
\hline Bisexual & $75(11.60 \%)$ \\
\hline Homosexual & $571(88.40 \%)$ \\
\hline Total & $646(100)$ \\
\hline & \\
\hline
\end{tabular}

Most physically active individuals had a masculine orientation (93.96\%), higher education levels $(61.30 \%)$, no partner $(94.12 \%)$, were classified as normal weight $(64.40 \%)$ and reported being dissatisfied with their body image $(69.66 \%)-54.96 \%$ due to being overweight and $14.70 \%$ due to being underweight. These results are shown in Table 3.

$81.27 \%$ of participants were homosexually active. Both crude and adjusted analyses showed an association between physically active homosexuals and masculine orientation (95\% CI, 4.89-19.34; 4.13-23.86), level of education (95\% CI, 2.28-9.03, 2.52-11.08) and dissatisfaction with body image due to being overweight (95\% CI, 0.12-0.55, 0.11-0.26). Associaiton between physically active homosexuals and marital status (95\% CI, 1.07-20.59) and body dissatisfaction due to being underweight (95\% CI, 0.07-0.61) was found only in the adjusted analysis. Thus, we found that physically active homosexuals were 9.93 times more likely to have a masculine orientation, 5.29 times more likely to have lower literacy levels and 4.71 times more likely to have a partner. 
TABLE 2 - Level of physical activity in homosexual men according to independent variables. Florianópolis, Santa Catarina, Brazil. 2014.

\begin{tabular}{|c|c|c|c|}
\hline Variable & $\begin{array}{l}\text { Active } \\
\mathrm{n}(\%)\end{array}$ & $\begin{array}{c}\text { Insufficiently active } \\
\mathrm{n}(\%)\end{array}$ & P-value \\
\hline \multicolumn{3}{|l|}{ Gender orientation } & \multirow{3}{*}{$<0.001$} \\
\hline Male & $553(96.51)$ & $54(73.97)$ & \\
\hline Female & $20(3.49)$ & 19 (26.03) & \\
\hline \multicolumn{3}{|l|}{ Sexual orientation } & \multirow{3}{*}{$<0.001$} \\
\hline Homosexual & 525 (91.62) & $46(63.01)$ & \\
\hline Bisexual & $48(8.38)$ & 27 (36.99) & \\
\hline \multicolumn{3}{|l|}{ Level of education } & \multirow{3}{*}{$<0.001$} \\
\hline High school diploma & 240 (41.89) & $10(13.70)$ & \\
\hline Higher education diploma & $333(58.11)$ & $63(86.30)$ & \\
\hline \multicolumn{3}{|l|}{ Marital status } & \multirow{3}{*}{$<0.001$} \\
\hline No partner & 537 (93.72) & $66(90.41)$ & \\
\hline Partner & $36(6.28)$ & 07 (09.59) & \\
\hline \multicolumn{3}{|l|}{ BMI } & \multirow{3}{*}{$<0.001$} \\
\hline Normal weight & $369(64.40)$ & 47 (64.38) & \\
\hline Overweight & $204(35.60)$ & $26(35.62)$ & \\
\hline \multicolumn{3}{|l|}{ Perception of body image } & \multirow{4}{*}{$<0.001$} \\
\hline Satisfied & $187(32.63)$ & 09 (12.33) & \\
\hline Dissatisfied due to being overweight & 301 (52.53) & $54(73.97)$ & \\
\hline Dissatisfied due to being underweight & $85(14.84)$ & $10(13.70)$ & \\
\hline
\end{tabular}

TABLE 3 - Odds ratio and confidence intervals of the crude and adjusted analyses of the association between level of physical activity, sociodemographic variables, body mass index (BMI) and perception of body image in homesexual men. Florianópolis, Santa Catarina, Brazil, 2014.

\begin{tabular}{|c|c|c|c|c|}
\hline \multirow[b]{2}{*}{ Variable } & \multicolumn{4}{|c|}{ PHYSICALLY ACTIVE } \\
\hline & $\begin{array}{l}\text { Crude analysis } \\
\text { OR }(95 \% \mathrm{CI})\end{array}$ & P-value & $\begin{array}{l}\text { Adjusted analysis } \\
\text { OR }(95 \% \mathrm{CI})\end{array}$ & P-value \\
\hline \multicolumn{5}{|l|}{ Gender orientation } \\
\hline Male & $9.73(4.89-19.34)$ & $<0.001$ & $9.93(4.13-23.86)$ & $<0.001$ \\
\hline Female & 1.0 & & 1.0 & \\
\hline \multicolumn{5}{|l|}{ Marital status } \\
\hline Partner & $2.38(0.56-10.10)$ & 0.240 & $4.71(1.07-20.59)$ & 0.0127 \\
\hline No partner & 1.0 & & 1.0 & \\
\hline \multicolumn{5}{|l|}{ Level of education } \\
\hline High school diploma & $4.54(2.28-9.03)$ & $<0.001$ & $5.29(2.52-11.08)$ & 0.001 \\
\hline Complete higher education & 1.0 & & 1.0 & \\
\hline \multicolumn{5}{|l|}{ BMI } \\
\hline Normal weight & $1.00(0.60-1.66)$ & 0.998 & $1.06(0.60-1.87)$ & 0.765 \\
\hline Overweight & 1.0 & & 1.0 & \\
\hline \multicolumn{5}{|l|}{ Body image } \\
\hline $\begin{array}{l}\text { Dissatisfied due to being } \\
\text { underweight }\end{array}$ & $0.40(0.16-1.04)$ & 0.061 & $0.22(0.07-0.61)$ & 0.001 \\
\hline $\begin{array}{l}\text { Dissatisfied due to being } \\
\text { overweight }\end{array}$ & $0.27(0.12-0.55)$ & $<0.001$ & $0.11(0.04-0.26)$ & $<0.001$ \\
\hline Satisfied & 1.0 & & 1.0 & \\
\hline
\end{tabular}

$\mathrm{OR}=$ odds ratio. $\mathrm{IR}$ = confidence interval. Wald test. Reference category (insufficiently active). Values in bold are significant at the $5 \%$ level. 


\section{DISCUSSION}

This study aimed to estimate the proportion of physically active men and investigate what factors may be associated with physical activity in men with bisexual and homosexual orientation.

Thus, the results show that $88.70 \%$ of participants were classified as being physically active. Of these, $91.62 \%$ were homosexuals and $8.38 \%$ were bisexuals. A study ${ }^{17}$ points out that the dissemination of scientific production contributes to the increase in the number of physically active individuals, because new individual and public health benchmarks are established, focusing on regular physical activity, and the efficiency or effectiveness of physical activity in the promotion of health and in the prevention, treatment and rehabilitation of diseases considered public health problems is clearly demonstrated.

Studies conducted in Brazil ${ }^{12}$, Texas ${ }^{18}$ and Canada ${ }^{19}$, (without regard for the sexual orientation of participants) have shown that physical activity is influenced by several factors, such as gender, demographics, age, level of education, lifestyle and eating habits.

The results found in this study demonstrate that the most participants $(61.30 \%)$ had higher education degree. Thesedata corroborate another study ${ }^{17}$ that has shown that the level of physical activity may be influenced by the level of education. Thus, it is inferred that having higher levels of education, having more knowledge about the benefits derived from regular physical activity, is associated with higher levels of physical activity, because information facilitates its practice.

Individuals with higher educational levels tend to have a more active and healthier lifestyle ${ }^{20}$, although this tendency decreases with age. ${ }^{21}$ In this sense, people should be continuously encouraged to practice of physical activity at all stages of life.

In this study $64.40 \%$ of participants were classified as having normal weight, i.e., they had BMI scores within the normal range. Nevertheless, a study ${ }^{22}$ has shown that due to the influence of Western media, gay men wish to lose weight and reduce total body mass. These findings converge with other studies that have been conducted in the past decade. ${ }^{23}$

In our study, most homosexual men $(91.62 \%)$ were classified as being physically active. Bisexual men were found to be insufficiently active. A study${ }^{22}$ has found that homosexual men are more physically active $(78.4 \%)$ than heterosexual men $(59.70 \%)$. On the other hand, another study ${ }^{23}$ has found that the sexual orientation of participants does not influence physical activity.

Most physically active individuals were single (93.72\%) and perceived themselves as having a masculine orientation (96.51\%). 52.53\% were dissatisfied with their body image. Of these, $14.84 \%$ due to being underweight. A study ${ }^{24}$ has shown that gay men tend to have higher levels of body dissatisfaction and may be at greater risk for symptoms of eating disorders compared to heterosexual men. The authors report that homosexual men show a preference for a more muscular physique, which is consistent with the male body ideal portrayed in contemporary media.

In this study, we found that physically active homosexuals were 9.93 times more likely to perceive themselves as having a masculine orientation $(95 \%$ 
CI, 4.89 to $19.34 ; 4.13$ to 23.86$)$. Although studies show that women tend to be more dissatisfied with their body image than are men ${ }^{24}$, this study found that homosexual men are also dissatisfied with their body image, both due to being overweight ( $95 \%$ CI, 0.12 to 0,$55 ; 0.11$ to 0.26 ) and due to being underweight (95\% CI, 0.07 to 0.61 ).

In this study, the prevalence of men's dissatisfaction with their body images (regardless of sexual orientation) was higher than that reported in Spain ${ }^{25}$ (34.7\%), in the $\mathrm{USA}^{26}(44.7 \%)$ and in Australia ${ }^{27}$ (54.8\%), similar to that reported in China $^{28}(68.2 \%)$ and lower that that reported in Finland ${ }^{29}(71.3 \%)$.

We also found an association with level of education $\mathrm{OR}=5.29(95 \% \mathrm{CI}$, 2.28 to $9.03 ; 2.52$ to 11.08 ) and marital status $\mathrm{OR}=4.71$ (95\% CI, 1.07 to 20.59). Thus, this study suggests that homosexuals who have partners and/or higher levels of education are more likely to be physically active than bisexuals.

A study conducted in Amsterdam, ${ }^{30}$ however, has found no association between the marital status of homosexuals and the practice of physical activity. In that study, both single and married homosexuals were classified as being physically active.

The information collected in this study and its preliminary results provide an important overview on the profile of homosexual and bisexual men in Brazil. This constitutes a first step in investigating factors associated with physical activity in men with different sexual orientations.

This study also aimed to encourage further research on the different factors that may be associated with heterosexual, bisexual and homosexual men and regular and satisfactory physical activity. The purpose of such research is to help these individuals adopt a healthy lifestyle and experience the benefits of physical activity.

Finally, this study was limited to male beach-goers with bisexual and homosexual orientation from a city in southern Brazil. This research, however, does not end here. Further studies should be carried out with the addition of heterosexual participants and a broader geographical scope, including other coastal cities of Brazil, in order to compare whether there are differences between the findings of this study and other research with different populations.

\section{REFERENCES}

1. Fortes LS, Almeida SS, Ferreira MEC. Insatisfação com a imagem corporal em modalidades esportivas do sexo masculino. J Bras Psiquiatr. 2013;62:101-07.

2. Silva DAS, Nunes HEG. Imagem corporal e estágios de mudança de comportamento para atividade física em universitários. Rev Bras Ativ Fís Saúde. 2014;19:597-600.

3. Kabir Y, Zafar TA, Waslien, C. Relationship between perceived body image and recorded body mass index among Kuwaiti female university students. Women Health. 2013;53:693-705.

4. IBGE. Instituto Brasileiro de Geografia e Estatística. Percepção do estado de saúde, estilos de vida e doenças crônicas. Disponível em: <http://www.ibge.gov.br/home/ estatistica/populacao/pns/2013/>. Acesso em: 17 fev. 2015.

5. Matsudo SM, Matsudo VKR, Araújo T, Andrade D, Andrade E, Oliveira L, et al. Nível de atividade física da população do estado de São Paulo: Análise de acordo com o gênero, idade, nível socioeconômico, distribuição geográfica e de conhecimento. Rev Bras Ciên e Mov. Brasília, 2002, 10(4):41-50.6. Giehl MWC, Schneider I JC, Corseuil HX, Benedetti TRB, d'Orsi E. Atividade física e percepção do ambiente em idosos: estudo populacional em Florianópolis. Rev Saúde Pública. 2012; 46(3):516-25. 
6. Mélo EM, Meneses AS, Junior AGS, Junior RSW, Barros MVG. Associação entre religiosidade, atividade física e comportamento sedentário em adolescentes. Rev Bras Ativ Fís Saúde. 2012, 17(5):359-69.

7. Scherer, RL, Lopes AS. Atividade física habitual em adultos com deficiência visual: uma revisão sistemática. Pensar a Prática. 2013;16:13-9.

8. Oliveira-Campos M, Cerqueira MBR, Rodrigues-Neto JF. Dinâmica populacional e perfil de mortalidade no município de Montes Claros (MG). Ciênc Saúde Colet. 2011;16:1303-10.

9. Teixeira, A, Júnior DB, Barros C, Andrade A, Marinho P. Diferença mínima clinicamente importante da qualidade de vida de pacientes com doença pulmonar obstrutiva crônica submetidos a um programa de reabilitação pulmonar. Rev Bras Ativ Fís Saúde. 2014;19:559-60.

10. Fiogbé E, Ferreira R, Sindorf MAG, Lopes CR, Moreno MA. Função autonômica cardíaca e nível de atividade física de pacientes com doença arterial coronariana. Rev Bras Ativ Fís Saúde. 2014;19:579-80.

11. Hallal PC, Bauman AA, Heath GW, Kohl HW, Lee I-Min, Pratt M. Physical activity: more of the same is not enough. Lancet. 2012;18-22.

12. Hallal PC, Andersen BO, Bull FC, Guthold R, Haskell W, Ekelund ULF. Global physical activity levels: surveillance progress, pitfalls, and prospects. Lancet. 2012;380:247-57.

13. Kinsey AC, Pomeroy WB, Martin CE. Sexual Behavior in the Human Male. Saunders, Philadelphia, 1948.

14. Coqueiros RS, Borges LJ, Araújo VC, Pelegrini A, Rodrigues AB. Medidas autorreferidas são validas para avaliação do estado nutricional brasileira? Rev Bras Cineantropom Desempenho Hum. 2009;11:113-19.

15. Stunkard A, Sorensen T, Schulsinger F. Use of the Danish Adoption Register for the study of obesity and thinness. In: S.S. KETY., L. P. ROWLAND., R.L. SIDMAN \& S.W. MATTHYSSE (Ed.). The Genetics of Neurological and Psychiatric Disorders. New York: Raven Press, 1983.

16. Moura-Junior JS, Ferreira DKS, Martins MO, Lima NMM. Nível de atividade física e perfil sociodemográfico dos usuários dos ambientes públicos de atividades físicas na cidade de João Pessoa-PB. R Bras Ci Saúde. 2011:15:349-56.

17. Korn L, Gonen E, Shaked Y, Golan M. Health perceptions, self and body image, physical activity and nutrition among undergraduate students in Israel. Plos One. 2013;8:585-43.

18. Harold WK, Craig CL, Lambert EV.The pandemic of physical inactivity: global action for public health. Lancet Physical Activity Series. 2012:294-305.

19. Dakanalis A, Riva G. Current considerations for eating and body-related disorders among men. Handbook on Body Image: Gender Differences, Sociocultural Influences and Health Implications, 2013:195-216.

20. Carvalho PHB, Filgueiras JF, Neves CM, Coelho FD, Ferreira MEC. Checagem corporal, atitude alimentar inadequada e insatisfação com a imagem corporal de jovens universitários. J Bras Psiquiatr. 2013;62:108-14.

21. Murray SB, Rieger E, Karlov L, Touyz S. W. Masculinity and femininity in the divergence of male body image concerns. Journal of eating disorders. 2013;1:11.

22. Murray SB, Touyz SW. Masculinity, Femininity and male body image: a recipe for future research. Int jour of men's health. 2012;11:227-39.

23. Smith AMA, Patrick KJ, Heywood W, Pitts MK, Richters J, Shelley JM, et al. Body mass index, sexual difficulties and sexual satisfaction among people in regular heterosexual relationships: a population-based study. Internal Medicine Journal, 2012;42:641-51.

24. Alvarenga MS, Philippi ST, Lourenço BH, Sato PM, Scagliusi FB. Insatisfação com a imagem corporal em universitárias brasileiras. J Bras Psiquiatr. 2010;59:44-51.

25. Roman B, Majem-Serra L, Ribas-Barba L, Pérez-Rodrigo C, Aranceta J. How many children and adolescents in Spain comply with the recommendations on physical activity? J Sports Med Phys Fitness. 2008;48:380-7.

26. Eaton DK, Kann L, Kinchen S, Shanklin S, Ross J, Hawkins J. Youth risk behavior surveillance-United States. MMWR Surveill Summ. 2008;57:21-31. 
27. Scully M, Dixon H, White V, Beckmann K. Physical activity and sedentary behaviour among Australian secondary students in 2005. Health Promot Int. 2007;22(3):236-45.

28. Li, M, Dibley MJ, Sibbritt DW, Zhou X, Yan H. Physical activity and sedentary behavior in adolescents in Xi'an City, China. J Adolesc Health. 2007;41:99-101.

29. Tammelin T, Ekelund U, Remes J, Näyhä S. Physical activity and sedentary behaviors among Finish youth. Med Sci Sports Exerc. 2007;39:1067-74.

30. Elling, A, Knop, de P, knopper, A. Gay/Lesbian sport clubs and events. Int. review for the sociology of sport. 2013;38:441-56.

\section{CORRESPONDING AUTHOR}

FABIANO AUGUSTO TEIXEIRA

Rua Pascoal Simone, 358, Coqueiros,

Florianópolis- SC, Brazil.

Phone number: (48) 96293344.

RECEIVED 16/02/2015

E-mail: fb teixeiradahotmail.com 